\title{
Msza święta i homilia według „Dyrektorium o mszach świętych z udziałem dzieci"
}

Wstęp

Praktyka przemawiania do dzieci jest powszechna, o czym świadczą liczne publikacje z pomocami do homilii dla dzieci, a także pomoce duszpasterskie zamieszczane w periodykach dla głosicieli słowa Bożego. Duszpasterze wykazują się ogromną inwencją twórczą w przygotowywaniu i przeprowadzaniu

1 Prezbiter diecezji włocławskiej, profesor doktor habilitowany, homileta, pedagog. Pracownik Uniwersytetu Papieskiego Jana Pawła II w Krakowie. Wykładowca homiletyki w Wyższym Seminarium Duchownym w Tarnowie i w Wyższym Seminarium Duchownym Księży Misjonarzy św. Rodziny. Redaktor naczelny kwartalnika teologicznego „Polonia Sacra”. Przewodniczący Stowarzyszenia Homiletów Polskich, członek Komisji Języka Religijnego PAN, członek Polskiego Towarzystwa Teologicznego (henryk.slawinski@upjp2.edu.pl).

Pierwotna wersja artykułu została opublikowana pt. Msza św. i homilia wedtug „Dyrektorium o Mszach św. z udziałem dzieci". Aktualność dyrektorium w 40. rocznicę powstania?, „Teologia i Człowiek” 28 (2014), s. 4, 97-115. 
homilii podczas mszy świętych z udziałem dzieci. Warto więc poddać tę kwestię naukowej refleksji homiletycznej. Sprzyja jej upływ ponad 4o lat od promulgacji Dyrektorium o mszach świętych z udziałem dzieci (1.11.1973). Jest ono podstawowym źródłem dla niniejszego opracowania. Innymi źródłami są wydane później dokumenty Stolicy Apostolskiej, dotyczące niektórych kwestii podjętych we wspomnianym dyrektorium: instrukcja Actio pastoralis (15.05.1969); instrukcja Ecclesiae de misterio (15.07.1997); list okólny Kaptan gtosiciel stowa, szafarz sakramentów i przewodnik wspólnoty $w$ drodze do trzeciego tysiaclecia chrześcijaństwa (19.03.1999); instrukcja Liturgiam authenticam (28.03.2001); Nowe ogólne wprowadzenie do Mszału rzymskiego. $Z$ trzeciego wydania Mszatu rzymskiego (18.03.2002); instrukcja Redemptionis sacramentum (25.03.2004).

Dokumenty wydawane przez Stolicę Apostolską potwierdzają lub doprecyzowują wcześniejsze wypowiedzi, ale też niekiedy odwołują to, co zostało uprzednio dopuszczone. Stąd też ważne jest odczytywanie ich z uwzględnieniem kolejności ich wydawania przez Stolicę Apostolską.

Uważna lektura dokumentów Nauczycielskiego Urzędu Kościoła składania do refleksji nad tym, co jest aktualne, a co się zdezaktualizowało w Dyrektorium o mszach świętych z udziałem dzieci, ze szczególnym uwzględnieniem posługi słowa. Próba odpowiedzi na to pytanie jest celem niniejszego artykułu. W związku z tym najpierw krótko przedstawimy genezę dokumentu i jego strukturę, następnie powiemy o zróżnicowaniu celebracji, które dyrektorium umożliwia, oraz o niektórych adaptacjach. W dalszej części podejmiemy kwestię aktualności Dyrektorium o mszach świętych z udziałem dzieci, a potem powiemy o dezaktualizacji niektórych adaptacji proponowanych przez nie. 


\section{Geneza Dyrektorium o mszach świętych z udziałem dzieci}

Mówiąc o genezie Dyrektorium o mszach świętych z udziałem dzieci, trzeba sięgnąć do motu proprio Piusa X o muzyce kościelnej z 1903 r., w którym wprowadzone zostało pojęcie „aktywnego uczestnictwa”. Określenie to stało się kluczowym kryterium ruchu liturgicznego XX w. i odnowy liturgicznej dokonanej przez Sobór Watykański $\mathrm{II}^{2}$. W soborowej konstytucji Sacrosanctum concilium wyrażone zostało pragnienie Kościoła, „aby wszystkich wiernych prowadzić do pełnego, świadomego i czynnego udziału w obrzędach liturgicznych, którego się domaga sama natura liturgii”3. Realizacji tego pragnienia miało służyć między innymi dopuszczenie zróżnicowania celebracji i dostosowania liturgii do rozmaitych grup wiernych przy zachowaniu istotnej jedność rytu rzymskiego ${ }^{4}$.

Tuż po Soborze Watykańskim II zaczęto pilnie poszukiwać szczególnie podczas I Synodu Biskupów w Rzymie w 1967 r. sposobu przystosowania liturgii tak, by ułatwić dzieciom uczestnictwo w niej. „Przewodniczący Rady do wykonania Konstytucji o Świętej Liturgii wyraźnie oświadczył, że nie może być mowy «o opracowaniu jakiegoś zupełnie odrębnego obrzędu, lecz raczej o zachowaniu, skróceniu lub opuszczeniu niektórych elementów; o doborze pewnych tekstów bardziej odpowiednich»”".

\footnotetext{
2 J. Hermans, Celebrować Eucharystię z dziećmi. Możliwości i granice nowego zjawiska liturgicznego wedtug „Dyrektorium o Mszach św. dla dzieci”, „Communio” 5 (1985), s. 107-108.

3 Sobór Watykański II, konst. o liturgii świętej Sacrosanctum concilium (4.12.1963), 14.

4 Por. Sobór Watykański II, konst. Sacrosanctum concilium, 38.

5 Kongregacja do spraw Kultu Bożego, dyrektorium o mszach świętych z udziałem dzieci Pueros Baptizatos (1.11.1973) [dalej: DMD], 3.
} 
W 1969 r. Święta Kongregacja Kultu Bożego wydała instrukcję Actio pastoralis ${ }^{6}$, w której podjęto kwestię odprawiania mszy świętej dla grup specjalnych. Instrukcja ta porządkowała sposób celebracji w małych grupach wiernych, w których świeccy w różny sposób głosili słowo Boże podczas liturgii?

W tym samym 1969 r. wydano Wprowadzenie ogólne do zreformowanego Mszału rzymskiego. Określono w nim wszystkie szczegóły dotyczące sprawowania mszy świętej z udziałem ludu. Z różnych stron świata nadsyłano do Stolicy Apostolskiej prośby o przygotowanie specjalnego dyrektorium o mszach świętych z udziałem dzieci, które miałoby uzupełnić wprowadzenie do Mszału rzymskiego. Kongregacja Kultu Bożego przygotowała więc taki dokument, pozwalając Konferencjom Biskupów i poszczególnym biskupom na dokonywanie pewnych adaptacji we mszach świętych z udziałem dzieci. Pomimo że Kongregacja Doktryny Wiary zgłosiła zastrzeżenia dotyczące zawartego w dyrektorium pozwolenia na głoszenie słowa Bożego podczas mszy świętej do dzieci przez świeckich, papież Paweł VI dnia 22 października 1973 r. podpisał Dyrektorium o mszach świętych z udziałem dzieci i polecił, by promulgowano je 1 listopada tegoż rokus.

\footnotetext{
6 Święta Kongregacja Kultu Bożego, instrukcja Actio pastoralis (15.05.1969), AAS 61 (1969), s. 806-811.

7 Por. A. Bugnini, The reform of the liturgy 1948-1975, trans. M. O'Connell, Collegeville, MN 1990, s. 432; H. Sławiński, Między ciągłością a zmianq. Teoria homilii w Stanach Zjednoczonych po II Soborze Watykańskim, Kraków 2008, s. 60-61. 8 Por. A. Bugnini, The reform of the liturgy..., dz. cyt., s. 444; S. DeLeers, A process for the assessment of liturgical preaching reflecting official Roman Catholic understanding of the homily. Thesis project presented to the Faculty of the Aquinas Institute of Theology, Saint Louis, MO, Ann Arbor, MI 1996, s. 35, przyp. 37.
} 


\section{Struktura Dyrektorium o mszach świętych z udziałem dzieci}

Zasadniczym celem dokumentu, podobnie jak całej soborowej odnowy liturgii, było umożliwienie dzieciom świadomego i czynnego udziału we mszy świętej ${ }^{9}$. Autorzy dokumentu stwierdzili, że Kościół w swojej trosce o dzieci „idzie za swoim Mistrzem, który «brał w objęcia dzieci i błogosławił» (Mk 10, 16)" ${ }^{\prime \prime}$. Uznali też pierwszorzędną rolę rodziców w dziele wychowania, w tym również wychowania religijnego: „Uczestnictwo dzieci we Mszy św. razem z rodzicami i innymi członkami rodziny bardzo sprzyja pielęgnowaniu ducha chrześcijańskiego w rodzinach" ${ }^{{ }_{11}}$.

Dyrektorium dotyczy dzieci, które jeszcze nie weszły w okres preadolescencji, przypadający na lata 10-13. Chodzi w nim więc o dzieci do około 10 roku życia. Sam dokument składa się z krótkiego wstępu (nr 1-7) i trzech rozdziałów:

- w pierwszym (nr 8-15) podane zostały „podstawowe zasady dotyczące różnych sposobów wprowadzania dzieci w liturgię eucharystyczną";

- w drugim (nr 16-19) jest mowa o mszach świętych z udziałem dorosłych, w których uczestniczą także dzieci;

- a trzeci (nr 20-54) omawia dokładniej msze święte z udziałem dzieci, którym towarzyszy niewielka liczba dorosłych ${ }^{12}$.

\footnotetext{
Por. Sobór Watykański II, konst. Sacrosanctum concilium, 14.

Por. DMD 3.

DMD 16.

DMD 7.
} 


\section{Zróżnicowanie celebracji mszy świętych z udziałem dzieci}

Dyrektorium bierze pod uwagę zróżnicowanie celebracji mszy świętych ze względu na różnorodność osób współtworzących zgromadzenie liturgiczne. Na pierwszym miejscu, co jest bardzo słuszne, wymieniane są msze święte z udziałem dorosłych, w których uczestniczą dzieci, a dopiero po niej msze święte z udziałem dzieci, którym towarzyszy niewielka liczba dorosłych.

Msze święte z udziałem dorosłych, w których uczestniczą dzieci

Ze względu na zróżnicowany wiek dzieci uczestniczących wraz z rodzicami we mszy świętej w dyrektorium uwzględnione zostały dwa możliwe rozwiązania:

- Gdy dzieci są całkiem małe, mogą pozostawać pod nadzorem starszych osób w jakimś osobnym miejscu. Dorośli, którzy zajmowaliby się tymi dziećmi podczas mszy świętej, mogliby je ewentualnie przyprowadzać tylko na końcowe błogosławieństwo: „Nawet maleńkie dzieci, które jeszcze nie potrafią lub nie chcą uczestniczyć we Mszy św., można przyprowadzić na zakończenie Mszy św., aby otrzymały błogosławieństwo wraz z całym zgromadzeniem. Podczas Mszy św. pozostają one w oddzielnym miejscu pod nadzorem starszych osób, np. pomocnic parafialnych ${ }^{{ }_{13} \text {. }}$

\footnotetext{
13 DMD 16. W praktyce dorośli zajmujący się dziećmi w innym pomieszczeniu nie uczestniczyliby we mszy świętej ani nie spełniliby chrześcijańskiego obowiązku uczestnictwa w niedzielnym zgromadzeniu eucharystycznym. Musieliby przyjść na mszę świętą odprawianą o innej porze, co nie zawsze byłoby możliwe. W celu uniknięcia tego problemu w niektórych kościołach w Stanach Zjednoczonych zbudowane jest osobne pomieszczenie za szybą, co sprawia, że hałas powodowany
} 
- W przypadku gdy dzieci uczestniczą we mszy świętej razem z dorosłymi, „trzeba pilnie uważać, aby dzieci nie poczuły się jakby lekceważone z tego względu, że nie są jeszcze zdolne do uczestnictwa i zrozumienia tego, co się podczas obrzędów odbywa i głosi. Przynajmniej w jakiś sposób trzeba uwzględnić ich obecność, np. zwracając się specjalnie do nich w pouczeniach (np. na początku i na końcu Mszy św.) oraz w jakiejś części homilii"14.

- Jeszcze inną adaptacją liturgii do dzieci proponowaną przez omawiane dyrektorium jest rozdzielenie liturgii słowa i liturgii eucharystycznej: „Jeżeli pozwalają na to warunki miejscowe i osobowe, od czasu do czasu można odprawić dla dzieci liturgię słowa wraz z homilią w jakimś miejscu osobnym, ale niezbyt odległym. Przed rozpoczęciem liturgii eucharystycznej dzieci te wprowadza się do miejsca, w którym dorośli sprawowali równocześnie własną liturgię słowa ${ }^{n_{1}}$.

Msze święte z udziałem dzieci, którym towarzyszy niewielka liczba dorosłych

Na drugim miejscu dyrektorium wymienia mszę świętą z udziałem dzieci, w których uczestniczą nieliczni dorośli. Zasadniczym principium, które przyświecało autorom dyrektorium, jest zasada czynnego i świadomego uczestnictwa dzieci we mszy świętej. Na czym więc ma polegać owo czynne i świadome uczestnictwo? Otóż dzieci powinny w jak największej liczbie

przez dzieci nie rozprasza uczestników liturgii, a dorosłym, którzy opiekują się dziećmi, zapewniony jest wizualny i akustyczny - dzięki nagłośnieniu - kontakt z pozostałymi uczestnikami mszy świętej.

14 DMD 17.

15 DMD 17. 
wypełniać takie czynności przed mszą świętą i podczas niej, jak: przygotowanie miejsca celebracji i ołtarza ${ }^{16}$, spełnianie funkcji kantora $^{17}$, śpiew w chórze, gra na instrumentach muzycznych ${ }^{18}$, czytanie lekcji ${ }^{19}$, odpowiadanie podczas homilii ${ }^{20}$, wypowiadanie wezwań modlitwy powszechnej, przynoszenie darów do ołtarza ${ }^{21}$. W celu ożywienia ich uczestnictwa można niekiedy dodawać nowe elementy, np. podanie powodów do wyrażania wdzięczności przed dialogiem rozpoczynającym prefację ${ }^{22}$.

W tych propozycjach adaptacji nie chodzi więc o aktywność dzieci jedynie dla przykucia ich uwagi i wprowadzenia porządku w grupie, ale o udział w liturgii, o mistagogię. Dyrektorium wyraźnie uwrażliwia, że „czynności zewnętrzne pozostaną bezowocne, a nawet szkodliwe, jeżeli nie będą służyć wewnętrznemu przeżywaniu uczestnictwa przez dzieci. Z tej racji również we Mszach dla dzieci ważnym czynnikiem jest święte milczenie" ${ }^{23}$.

Ponadto uczestnictwu dzieci w liturgii ma pomóc celebrowanie mszy świętej przez kapłana w sposób „uroczysty, braterski i refleksyjny. Atmosfera taka potrzebna jest bardziej niż we Mszach dla dorosłych; a ma ją wytworzyć celebrans"24. Kapłan celebrujący powinien zadbać „o prostotę, dostojeństwo i piękno w gestach”25. Może się zwróci do dzieci własnymi słowami, na przykład zachęcając je do aktu pokutnego,

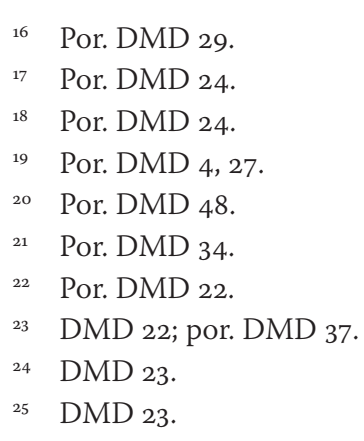


do modlitwy nad darami i Modlitwy Pańskiej, do przekazania sobie znaku pokoju albo też do Komunii świętej. Stosowany przez niego język powinien być zrozumiały dla dzieci. Celebrujący kapłan „powinien jednak unikać zbyt dziecinnego sposobu mówienia" ${ }^{26}$.

\section{Aktualność Dyrektorium o mszach świętych z udziałem dzieci w odniesieniu do homilii}

Dyrektorium powstało tuż po Soborze Watykańskim II, w okresie dużej twórczości liturgicznej. Część wskazań w nim zawartych do dziś nie straciła niczego ze swej aktualności.

Uznanie rodziców za głównych wychowawców swoich dzieci

Dyrektorium zachowuje aktualność w zakresie tych wskazań, które są stałym nauczaniem Kościoła. Chodzi tu przede wszystkim o podkreślenie prawdy o tym, że rodzice są pierwszymi i głównymi wychowawcami swoich dzieci. Stąd też słuszne jest wyeksponowanie w dyrektorium na pierwszym miejscu mszy świętej, w której dzieci uczestniczą wraz z dorosłymi. Jeśli zaś już organizuje się mszę świętą, w której liczba dzieci jest znaczna, na przykład dla dzieci szkolnych, trzeba ją tak zorganizować, aby również dorośli mogli odnieść pożytek z uczestnictwa w niej ${ }^{27}$.

\footnotetext{
26 DMD 23.

27 DMD 19; por. DMD 10; J. Przybyłowski, Msza święta dla dzieci. Refleksja teologiczno-pastoralna, „Ateneum Kapłańskie” 154 (2010), z. 2, s. 325; I. Kosmana, Jak mówić dzieciom o Bogu, w kościele $i$ w domu, „Łódzkie Studia Teologiczne” 19 (2010), s. 81-83.
} 
Przygotowywanie dzieci do udziału

we mszy świętej z dorosłymi

Sprawowanie Eucharystii z dziećmi powinno prowadzić je do wspólnego świętowania z pozostałymi członkami wspólnoty parafialnej i do celebrowania mszy z udziałem dorosłych, a szczególnie do regularnego świętowania niedzielnej mszy świętej, na której gromadzi się obowiązkowo chrześcijańska wspólnota ${ }^{28}$. Słuszne jest więc spostrzeżenie, że adaptacje stosowane do dzieci nie powinny przeradzać się w zupełnie odrębne obrzędy, które różniłyby się zbytnio od obrzędów z udziałem dorosłych ${ }^{29}$.

Nie można mówić ani robić czegoś, co później trzeba by odwoływać, gdy dzieci podrosną! Z tego względu adaptacje ze względu na wiek uczestników liturgii mają swoje granice: „nigdy nie należy zmieniać i przystosowywać dla dzieci: «aklamacji i odpowiedzi wiernych na pozdrowienia kapłana», modlitwy Pańskiej, formuły trynitarnej na końcu błogosławieństwa, którym kapłan zamyka obrzędy mszalne"30.

Zaangażowanie dzieci do pełnienia funkcji lektorów i kantorów

Soborowa odnowa liturgii zachęcała do wzmożenia czynnego uczestnictwa oraz do tego, by zarówno duchowni, jak i świeccy

\footnotetext{
28 Por. DMD 21.

29 DMD 21.

3o DMD 39. Błędem jest stosowane przez niektórych duszpasterzy pozdrawiania dzieci na początku mszy świętej słowami: „Niech będzie pochwalony Jezus Chrystus” i oczekiwania odpowiedzi: „Na wieki wieków. Amen”. Niewłaściwe jest także śpiewanie piosenki „Przepraszam Cię, Boże, w skrzywdzonym człowieku, przepraszam dziś wszystkich was", zamiast dopuszczalnych w mszale i bardzo zróżnicowanych formuł aktu pokuty.
} 
czynili tylko to i wszystko to, co należy do nich z natury liturgii i na mocy przepisów liturgicznych ${ }^{31}$. Cennym i aktualnym sposobem zaangażowania dzieci jest postulowane w dyrektorium dobierania lektorów i kantorów spośród dzieci bądź spośród dorosłych tak, by dzięki różnorodności głosów unikać nużącej jednostajności ${ }^{32}$.

Homilie dialogowane z elementami wizualizacji

Według dyrektorium „we wszystkich Mszach z udziałem dzieci ważne zadanie spełnia homilia: która wyjaśnia słowo Boże. Homilia skierowana do dzieci niekiedy będzie przechodzić w dialog z nimi, chyba, że lepiej jest, aby dzieci słuchały w milczeniu"33. Dyrektorium zauważa ponadto, iż liturgia nie powinna nigdy wydawać się czymś suchym i tylko intelektualnym $^{34}$, i dlatego dopuszcza ilustrowanie homilii dziełami sztuki przygotowanymi przez same dzieci, o czym będzie mowa poniżej ${ }^{35}$.

Według dyrektorium homilia powinna czasami stawać się dialogiem z dziećmi ${ }^{36}$. W ten sposób dzieci w owym czasie zostałyby bardziej uprzywilejowane we współwykonaniu homilii aniżeli dorośli, którym instrukcja Liturgicae instaurationes oznajmiała, że „mają się powstrzymać od komentarzy czy

\footnotetext{
31 Sobór Watykański II, konst. Sacrosanctum concilium, 30, 28.

32 DMD 24.

33 DMD 48.

34 Por. DMD 35.

35 Por. DMD 36.

36 „We wszystkich mszach z udziałem dzieci ważne zadanie spełnia homilia, która wyjaśnia słowo Boże. Homilia skierowana do dzieci niekiedy będzie przechodzić w dialog z nimi, chyba, że lepiej jest, aby dzieci słuchały w milczeniu". DMD 48 (zob. nr 46 na temat śpiewu dzieci po homilii, gdy było jedno czytanie).
} 
czegoś podobnego" ${ }^{37}$. Natomiast według instrukcji Ecclesiae de misterio z 1997 r. „możliwość «dialogu» podczas homilii może być czasem roztropnie wykorzystywana przez kapłana sprawującego Mszę św. jako forma objaśnienia, co jednak nie oznacza złożenia na innych obowiązku głoszenia słowa" ${ }^{38}$.

Odnosząc się do tematu wizualizacji, dyrektorium zauważa, iż „sama liturgia Mszy zawiera wiele elementów wizualnych”, jak np.: „adoracja krzyża, paschał, gromnice w święto Ofiarowania Pana Jezusa, rozmaitość kolorów i ozdób liturgicznych"40. Na pierwszym miejscu wymienione są więc elementy, które składają się na liturgię odpowiednio do okresu liturgicznego. $\mathrm{Na}$ drugim miejscu dyrektorium wymienia inne elementy wizualne. Warunkiem ich wprowadzenia jest to, by pozwoliły „dzieciom uchwycić wzrokiem wielkie dzieła Boże dokonane dzięki stworzeniu i odkupieniu i które poprzez doznania wizualne wspomagają modlitwę"41.

Dyrektorium stwierdza, że „może być również pożyteczne posługiwanie się obrazami przygotowanymi przez same dzieci dla zilustrowania homilii, dla obrazowego przedstawienia wezwań Modlitwy powszechnej, dla inspirowania modlitwy myślnej"42. Zauważmy, że chodzi tu wyraźnie o uaktywnienie dzieci w domu, żeby przygotowały się do liturgii, o zaangażowanie dzieci w przygotowanie tego, co potrzebne do przeżywania liturgii, a zwłaszcza homilii. Nie chodzi o to, by celebrans przygotowywał wszystko sam i sprowadził dzieci do roli

\footnotetext{
37 Instrukcja Liturgicae instaurationes, 2a; por. T.H. Sieg, Models of Preaching, „Worship” 59 (1985) nr 3, s. 223.

${ }_{38}$ Instrukcja Ecclesiae de misterio, art. $3, \mathbb{\$} 3$.

39 DMD 35.

40 DMD 35.

41 DMD 35.

42 DMD 36.
} 
widzów. Samo przygotowanie ma walor ewangelizacji i troski duszpasterskiej.

\section{Świadome i czynne uczestnictwo}

Również w innym miejscu dyrektorium mówi o zaangażowaniu dzieci przed liturgią: chodzi o przygotowanie i przyozdabianie miejsca na odprawianie mszy świętej oraz paramentów liturgicznych: kielicha, pateny i ampułek ${ }^{43}$. Są to czynności należne ministrantom i służbie ołtarza. Dzieci mogą spełniać te funkcje.

Dopuszczoną adaptacją jest procesyjne wejście wszystkich dzieci wraz z celebransem na początku mszy świętej. Służyłoby ono uświadomieniu dzieci, że „w tej chwili tworzy się wspólnota"44. Pomocą do zaangażowania dzieci w świadome i czynne uczestnictwo we mszy świętej jest ponadto wybór odpowiedniej pory dnia, „która bardziej odpowiada warunkom ich życia, tak aby dzieci były jak najbardziej otwarte na słuchanie słowa Bożego i sprawowanie Eucharystii"45. Innym sposobem jest zaangażowanie dzieci w spontaniczną modlitwę wiernych. Dzieci nieprzygotowane nie potrafią się zaangażować. Gdy przyjedzie rekolekcjonista i proboszcz poprosi, by on poprowadził spontaniczną modlitwę z dziećmi, które wcześniej nie miały takiego doświadczenia, zapanuje jedynie dezorientacja. Toteż „Od czasu do czasu trzeba zorganizować wspólne modlitwy, do których dzieci mogą się włączyć nawet spontanicznie" ${ }^{\prime \prime}$.

\footnotetext{
43 DMD 29.

44 DMD 34.

45 DMD 26.

46 DMD 27.
} 
Zawsze trzeba uważać, żeby wszelkie adaptacje służyły raczej skupieniu niż rozproszeniu dzieci ${ }^{47}$. Świadome i czynne uczestnictwo to nie aktywizm - li tylko zewnętrzne zaangażowanie. Podczas liturgii, nie mniej od zewnętrznej akcji, ważne jest przeżycie wewnętrzne. I, jak zauważa dokument Redemptionis sacramentum, należy pamiętać o tym, że „moc czynności liturgicznych nie zawiera się w często zmienianych obrzędach liturgicznych, lecz w słowie Boga i w sprawowanej tajemnicy, w które należy coraz głębiej wnikać" 48 .

Prefekt Kongregacji Nauki Wiary kard. Józef Ratzinger wielokrotnie w swoich pismach podkreślał zupełnie niewłaściwe rozumienie soborowego postulatu aktywnego uczestnictwa (participatio actuosa), które zostało sprowadzone do czystego aktywizmu i konieczności powszechnego zaangażowania wszystkich wiernych w akcję liturgiczną ${ }^{49}$.

Przy teologicznym rozumieniu aktywnego uczestnictwa zewnętrzna aktywność ma znaczenie drugorzędne. Gdy katechizm mówi o tym, że liturgię celebruje cała wspólnota, Ciało Chrystusa zjednoczone ze swoją Głową koncentruje się wpierw na realizacji kapłaństwa wspólnego polegającego na składaniu duchowych ofiar - a więc na upodabnianiu się do Logosu. Teologia aktywnego uczestnictwa podkreśla przede wszystkim znaczenie mistagogii, a więc prawdziwej liturgicznej akcji i formacji.

Weryfikacją tego, na ile dzieci świadomie i czynnie uczestniczą w eucharystycznej ofierze i uczcie, jest ich postawa po zakończeniu celebracji. Aktualny pozostaje postulat dyrektorium, aby

\footnotetext{
47 DMD 32.

${ }_{48}$ Kongregacja ds. Kultu Bożego i Dyscypliny Sakramentów, instrukcja Redemptionis sacramentum, 39.

49 J. Ratzinger, Nowa pieśń dla Pana. Wiara w Chrystusa a liturgia dzisiaj, tłum.

J. Zychowicz, Kraków 1999, s. 184.
} 
dzieci stale uczyły się „lepiej głosić Chrystusa w domu i poza domem, w rodzinie i wśród rówieśników, żyjąc wiarą" ${ }^{5_{5}}$.

Zachowywanie milczenia we mszy świętej z udziałem dzieci

Nic więc dziwnego, że dyrektorium zachęca do zachowywania świętego milczenia również podczas mszy świętych z udziałem dzieci, argumentując przy tym, że „dzieci także są zdolne do refleksji i rozważania na swój sposób. Jednakże trzeba nimi pokierować, aby w różnych chwilach (np. po Komunii św. lub nawet po homilii) umiały zwrócić myśli ku sobie, albo na krótko oddać się rozważaniu, albo w sercu swoim wielbić Boga i modlić się do Niego" ${ }^{51}$.

Milczenie spełnia dodatkową funkcję wychowawczą uwrażliwia na fakt, że podczas liturgii nie wolno się śpieszyć. W tym kontekście należy się również starać, i to bardziej niż we mszach dla dorosłych, „aby teksty liturgiczne były czytane bez pośpiechu, w sposób zrozumiały i z zachowaniem wymaganych pauz" ${ }^{2}$.

Jeszcze jednym walorem milczenia jest to, że sprzyja wnikaniu w misterium celebrowane we mszy świętej, która nie jest ani katechezą, ani czymś tylko intelektualnym. Może się zdarzyć, że dzieci nie będą wszystkiego rozumiały, ale będzie na nie oddziaływać podniosła i dostojna atmosfera oraz szacunek do słowa Bożego. Nie można nawet oczekiwać ani wymagać, aby dzieci rozumiały wszystkie szczegóły liturgii. „Także w codziennym swoim życiu nie zawsze rozumieją wszystko,

\footnotetext{
$50 \quad$ DMD 55.

${ }^{51}$ DMD 37.

52 DMD 37.
} 
co przeżywają razem z dorosłymi i nie jest to dla nich czymś przykrym" 53 .

\section{Dezaktualizacja Dyrektorium o mszach świętych z udziałem dzieci}

Choć, jak wykazano wyżej, Dyrektorium o mszach świętych z udziałem dzieci zachowuje aktualność w wielu kwestiach, znajdują się w nim wszelako szczegółowe wskazania, które ową aktualność utraciły, ponieważ zostały zmodyfikowane przez Stolicę Apostolską w późniejszych dokumentach. Modyfikacje dotyczą takich zagadnień jak: dostosowanie czytań, czytanie ich z podziałem na role, rozdzielenie liturgii słowa i liturgii eucharystycznej, adaptacje tekstów liturgicznych oraz homilie głoszone przez świeckich we mszach świętych z udziałem dzieci.

\section{Dostosowanie czytań}

Według omawianego dyrektorium w niedziele i święta wolno wybrać spośród przewidzianych czytań dwa lub nawet tylko jedno z nich, przy czym nigdy nie można rezygnować z czytania wziętego z Ewangelii ${ }^{54}$. Racją, która została uznana za wystarczającą do rezygnacji z pozostałych czytań, jest ich trudnośćc5. Z tego samego powodu, czyli ze względu na poziom intelektualny dzieci, dyrektorium dopuszczało opuszczenie jednego czy drugiego wiersza w czytaniu biblijnym, sugerując przy tym

\footnotetext{
53 DMD 2.

54 DMD 42.

55 DMD 42.
} 
zachowanie ostrożności, „by nie okaleczyć treści tekstu albo ducha i poniekąd stylu Pisma Świętego" ${ }^{\prime \prime}$.

Inną akomodacją wprowadzoną przez dyrektorium we mszach świętych z udziałem dzieci jest rezygnacja z psalmu i śpiewu „Alleluja” na rzecz chwili ciszy przeznaczonej na medytację․ Jeszcze inna akomodacja dotyczy kolejności poszczególnych obrzędów liturgii słowa. Jeśli we mszy świętej z udziałem dzieci nie proklamuje się innego czytania poza Ewangelią, bezpośrednio po niej może nastąpić śpiew psalmu bądź homilia, a psalm może być wykonany po homilii ${ }^{8}$.

Inne stanowisko w odniesieniu do powyższych kwestii przedstawiła Stolica Apostolska w instrukcji Redemptionis sacramentum z $2004 \mathrm{r}$. Według niej „nie wolno opuszczać i zmieniać przepisanych czytań biblijnych, a zwłaszcza «czytań ani psalmu responsoryjnego, w których zawiera się słowo Boże, nie wolno zastępować innymi tekstami, nie biblijnymi»"

Niezrealizowanym w Polsce postulatem dyrektorium jest zalecenie, aby poszczególne Konferencje Biskupów postarały się o ułożenie lekcjonarza do mszy świętych z udziałem dzieci' ${ }^{60}$. Taki lekcjonarz rozwiązałby przynajmniej do pewnego stopnia problem trudności czytań i musiałby zostać zaaprobowany przez Kongregację Kultu Bożego.

\footnotetext{
$56 \quad$ DMD 43.

57 DMD 46.

58 DMD 46.

59 Kongregacja ds. Kultu Bożego i Dyscypliny Sakramentów, instrukcja Redemptionis sacramentum, 62.

6o Por. DMD 43.
} 
Czytanie tekstów biblijnych z podziałem na role

Kolejną modyfikacją liturgii słowa dozwoloną przez dyrektorium, która została zrewidowana przez Stolicę Apostolską, jest wykonywanie czytań biblijnych z podziałem na role. Według dyrektorium „tam, gdzie tekst czytania takie rozwiązanie podsuwa, może okazać się pożyteczne, aby dzieci odczytały go dzieląc między siebie role, jak to zostało ustalone przy czytaniu opisu Męki Pańskiej w Wielkim Tygodniu"61. Inne stanowisko w tej sprawie przedstawiła Stolica Apostolska w Nowym ogólnym wprowadzeniu do Mszału rzymskiego z trzeciego wydania Mszału rzymskiego z 2002 r. Czytam w nim, że „nie wypada jednak, aby kilka osób dzieliło między siebie jedyny element celebracji, np. by dwóch lektorów wykonywało, jeden po drugim, to samo czytanie. Wyjątkiem jest opis Męki Pańskiej”².

Rozdzielenie liturgii słowa i liturgii eucharystycznej

Trudne do pogodzenia z soborowym nauczaniem o mszy świętej jako jednym akcie liturgicznym, na który w sposób nierozdzielny składają się liturgia słowa i Eucharystii, jest zawarte $\mathrm{w}$ dyrektorium pozwolenie na wyprowadzenie dzieci na inne miejsce na czas liturgii słowa. Według dyrektorium, jeśli w jakiejś wspólnocie są odpowiednie warunki lokalowe, a także przygotowany personel, „od czasu do czasu można odprawić dla dzieci liturgię słowa wraz z homilią w jakimś miejscu osobnym, ale niezbyt odległym. Przed rozpoczęciem liturgii

\footnotetext{
${ }^{6}$ DMD 47.

${ }^{62}$ „Minime vero congruit ut plures unicum elementum celebrationis inter se dividant: ex. gr. eadem lectio a duobus, unus post alium, lecta, nisi agatur de Passione Domini". Ogólne wprowadzenie do Mszału rzymskiego, 109 [dalej: OWMR].
} 
eucharystycznej dzieci te wprowadza się do miejsca, w którym dorośli sprawowali równocześnie własną liturgię słowa" ${ }^{33}$.

Pozwolenie takie wynikało z faktu, że w okresie przed Soborem Watykańskim II świadomość tego, iż liturgia słowa i liturgia eucharystyczna stanowią jeden i ten sam akt kultu, była nieporównywalnie mniejsza niż obecnie. Jeszcze nawet bezpośrednio przed Soborem Watykańskim II Josef Andreas Jungmann odróżniał „przed-mszę”, czyli liturgię słowa, od "mszy ofiarniczej". Obrzędy wstępne i liturgia słowa nie były traktowane jako istotna część celebracji eucharystycznej, ale jako przygotowanie do najistotniejszej części mszy świętej, która zaczynała się w momencie przygotowania darów ofiarnych. Spóźnienie się do tego momentu na mszę świętą w dni obowiązujące katolików do udziału w niej traktowane było w teologii moralnej jako grzech lekki ${ }^{64}$.

Dzięki soborowemu nauczaniu o mszy świętej jako jednym akcie kultu i posoborowej wykładni tego nauczania wzrosło wśród teologów przekonanie, że nie wolno rozdzielać poszczególnych części mszy świętej. Wyrazem aktualnej świadomości Kościoła w tym zakresie jest wypowiedź Kongregacja Kultu Bożego i Dyscypliny Sakramentów o tym, że „nie wolno oddzielać jednej od drugiej ani sprawować ich w różnym czasie i miejscu. Nie wolno również poszczególnych części Mszy Świętej sprawować w różnych porach tego samego dnia" ${ }^{5}$. Dodatkowym

\footnotetext{
63 DMD 17.

${ }_{64}$ Por. M. Kunzler, Liturgia Kościoła, Poznań 1999, s. 334; H. Sławiński, Liturgia słowa i liturgia eucharystyczna jako jeden akt liturgiczny, „Przegląd Homiletyczny” 11 (2007), s. 19-32.

${ }_{65}$ Kongregacja ds. Kultu Bożego i Dyscypliny Sakramentów, instrukcja Redemptionis sacramentum, 6o. Wypowiedź ta nawiązuje do soborowej konstytucji o liturgii świętej Sacrosanctum concilium, 56: „Dwie części, z których w pewnym stopniu składa się msza święta, a mianowicie liturgia słowa i liturgia euchary-
} 
argumentem przeciwnym omawianej praktyce postulowanej przez dyrektorium jest znak przewodniczącego liturgii, który powinien być jeden dla całego zgromadzenia liturgicznego: od początku do końca celebracji. Niełatwo bowiem pogodzić wspomniane pozwolenie dyrektorium z późniejszym oświadczeniem Stolicy Apostolskiej zawartym w Ogólnym wprowadzeniu do Mszału rzymskiego, w którym czytamy, że „jeden i ten sam kapłan winien zawsze wykonywać urząd posługi przewodniczenia we wszystkich częściach celebracji, z wyjątkami właściwymi Mszy Świętej, w której bierze udział biskup" ${ }^{66}$.

\section{Adaptacje tekstów liturgicznych}

Dyrektorium o mszach świętych z udziałem dzieci przewidywało wiele akomodacji tekstów liturgicznych w celu ułatwienia dzieciom bardziej świadomego uczestnictwa we mszy świętej. Wśród tych akomodacji znalazła się na przykład możliwość zastąpienia w uroczystości Credo nicejsko-konstantynopolitańskiego symbolem apostolskim ${ }^{67}$. Ponadto w celu ułatwienia dzieciom uczestnictwa w śpiewie dyrektorium umożliwiło wprowadzenie popularnych przekładów „Chwała”, „Wierzę”,

styczna, tak ściśle wiążą się z sobą, że stanowią jeden akt kultu. Dlatego Sobór święty usilnie zachęca duszpasterzy, aby w katechezie gorliwie uczyli wiernych uczestniczenia w całej mszy świętej, zwłaszcza w niedziele i obowiązujące święta”. Zob. także: Święta Kongregacja ds. Sakramentów i Kultu Bożego, instrukcja Inaestimabile donum, 4.

${ }_{66}$ OWMR 108. W nr 92 OWMR zamieszczone jest wyjaśnienie, że biskup kieruje wszelką prawowitą celebracją Eucharystii bądź to osobiście, bądź to przez prezbiterów jako swoich współpracowników. W przypadku gdy biskup nie przewodniczy osobiście całej Eucharystii, ale powierza to komuś innemu, wtedy wypada, aby przewodniczył przynajmniej liturgii słowa, a na koniec mszy świętej udzielił zgromadzonym błogosławieństwa.

${ }^{67}$ Por. DMD 49. 
„Święty” $i$ „Baranku Boży” 68 . Jednakże dyrektorium nie pozwoliło na jakiekolwiek zmiany, z wyjątkiem zatwierdzonych przez kompetentną władzę. Oznacza to, że nawet dyrektorium, które pozostawia celebransom wiele swobody, nie może pozwolić na to, by dowolnie zamieniano "Chwała” w śpiew na przykład: „Chwalimy Pana dziś za łaskę, którą daje nam”, a aktu pokuty na przykład na śpiew: „Przepraszam Cię, Boże, skrzywdzony w człowieku”, natomiast „Święty” na śpiew: „Święty, Święty... dziś wznosimy nasze ręce, uwielbiając miłość Twą, Święty, Święty".

Omawiane dyrektorium sugeruje nawet możliwość przystosowania do potrzeb dzieci tekstów modlitw z Mszału rzymskiego, ponieważ modlitwy zostały ułożone z myślą o wiernych dorosłych ${ }^{69}$. Tymczasem instrukcja Redemptionis sacramentum w numerze 59 bardzo surowo piętnuje praktykę dokonywania przez kapłanów, diakonów lub świeckich zmian tekstów liturgicznych według własnego uznania: „Powinien zniknacć godny napiętnowania zwyczaj, że kapłani lub diakoni albo wierni, tu i ówdzie według swojego uznania, zmieniają lub zniekształcają teksty świętej liturgii, jakie są zobowiązani wypowiedzieć. Postępując w ten sposób, czynią celebrację świętej liturgii niepewną, a nierzadko fałszują jej autentyczny sens"7o.

Ponadto trzeba tu uwzględnić rozporządzenia instrukcji Kongregacja Kultu Bożego i Dyscypliny Sakramentów Liturgiam authenticam z 28 marca 2001 r., według której akomodacje nie mogą prowadzić do zmian teologicznego znaczenia tekstów liturgicznych ${ }^{71}$. Wobec tej zasadniczej troski o dokładną

\footnotetext{
68 Por. DMD 31.

69 Por. DMD 51.

7o Kongregacja ds. Kultu Bożego i Dyscypliny Sakramentów, instrukcja Redemptionis sacramentum, 59.

71 Kongregacja Kultu Bożego i Dyscypliny Sakramentów, instrukcja Liturgiam authenticam (28.03.2001), 22.
} 
treść doktrynalną tekstów liturgicznych ustąpić musi nawet troska o ich artystyczny wydźwięk ${ }^{72}$. Teksty liturgiczne są głosem modlącego się Kościoła, a nie głosem poszczególnych grup albo pojedynczych ludzi: czy to dorosłych, czy dzieci³ ${ }^{\mathrm{7}}$.

\section{Homilie głoszone przez świeckich we mszach świętych z udziałem dzieci}

Omawiane tu dyrektorium straciło swą aktualność w kwestii głosicieli słowa Bożego. Według tego dokumentu „nic nie stoi na przeszkodzie, aby jeden z dorosłych uczestników Mszy św. dla dzieci, za zgodą proboszcza lub rektora kościoła, przemówił do dzieci po Ewangelii, zwłaszcza jeśli kapłanowi trudno przychodzi dostosować się do mentalności dzieci" ${ }^{74}$. Owo rozporządzenie zostało wyraźnie odwołane przez dokument Ecclesiae de misterio z 1997 r., przygotowany przez wiele dykasterii Kurii Rzymskiej, oraz przez dokument Redemptionis sacramentum z 2004 $\mathrm{r}^{75}$ Rezerwują one homilię podczas mszy świętej dla osoby wyświęconej. Dopuszczają natomiast,

\footnotetext{
72 Por. Kongregacja Kultu Bożego i Dyscypliny Sakramentów, instrukcja Liturgiam authenticam, 20, 25.

73 Por. Kongregacja Kultu Bożego i Dyscypliny Sakramentów, instrukcja Liturgiam authenticam, 27.

74 DMD 24.

75 Kongregacja ds. Kultu Bożego i Dyscypliny Sakramentów, instrukcja Redemptionis sacramentum, 65-66: „Należy pamiętać, iż w myśl zapisu kan. $767 \$ 1$ wszelkie wcześniejsze przepisy, które dopuszczały wiernych nie wyświęconych do wygłaszania homilii w czasie celebracji eucharystycznej uznaje się za zniesione. Owo dopuszczenie zostaje cofnięte, tak że nie może być przywrócone mocą żadnego zwyczaju. Zakaz dopuszczania świeckich do głoszenia homilii podczas celebracji Mszy świętej odnosi się również do alumnów seminariów, studentów teologii i tych, którzy podjęli się zadania, jak się określa, «asystentów duszpasterskich», nie wyłączając również wszelkich innych grup, ruchów, wspólnot lub stowarzyszeń świeckich".
} 
aczkolwiek tylko w wyjątkowych przypadkach, składanie świadectw przez osoby świeckie podczas liturgii eucharystycznych. Mogą one wówczas stanowić część homilii wygłoszonej przez celebransa. Składane „świadectwa nie powinny przybierać takiej formy, która zatarłaby różnicę między nimi a homilią̧" ${ }^{\prime 6}$. Zasadniczo jednak świadectwa te powinny być przeniesione poza celebrację mszy świętej albo - z ważnych przyczyn można je przekazać po odmówieniu przez kapłana modlitwy po Komunii. Również wtedy „informacje te i świadectwa w żadnym razie nie powinny posiadać takich cech, aby mogły być kojarzone z homilią ani być powodem nie wygłoszenia homilii w ogóle" 7 .

Jakkolwiek świeccy uczestniczą w kapłaństwie Chrystusowym, wspólnym dla wszystkich wiernych, jest ono różne co do istoty od kapłaństwa urzędowego, czyli hierarchicznego, które jest służebne wobec kapłaństwa powszechnego ${ }^{78}$. Kapłan celebruje mszę świętą in persona Christi ${ }^{79}$ : Chrystus jest obecny także w jego nauczaniu i przewodniczeniu wiernym, do czego kapłan jest osobiście powołany ${ }^{80}$.

\footnotetext{
${ }^{76}$ Międzydykasterialna instrukcja o niektórych kwestiach dotyczących współpracy wiernych świeckich w ministerialnej posłudze kapłanów Ecclesiae de misterio (15.08.1997), art. 3, $\$ 2$.

77 Kongregacja ds. Kultu Bożego i Dyscypliny Sakramentów, instrukcja Redemptionis sacramentum, 74 .

78 Por. KKK 1547; cyt. z KK 10.

79 Sobór Watykański II, konst. dogmatyczna o Kościele Lumen gentium, 10.

8o Jan Paweł II, Przemówienie do uczestników zgromadzenia plenarnego Kongregacji ds. Duchowieństwa, Parafia i jej pasterz (23.11.2001), „L'Osservatore Romano” 24.2 (2002) nr 4, s. 29-30.
} 


\section{Wnioski}

Mając na uwadze wskazania Stolicy Apostolskiej dotyczące mszy świętych i homilii dla dzieci, należy wystrzegać się legalizmu: myślenia ograniczonego jedynie do rubryk. Przepisy Stolicy Apostolskiej to nie sztywny gorset. Niekiedy muszą być one korygowane pod wpływem praktyki duszpasterskiej, ale zawsze przy zachowaniu zasady lex orandi - lex credendi, aby doktrynalna treść tekstów liturgicznych nie doznała uszczerbku. Troska o wierność wobec przepisów liturgicznych nie może gasić duszpasterskiej kreatywności. Ta zaś powinna znajdować nie tyle pragmatyczne, co teologiczne uzasadnienie. Ważne jest uwzględnianie fundamentalnej zasady, która przyświecała Soborowi Watykańskiemu II podczas odnowy liturgii - aby umożliwić wiernym świadome, czynne i pełne uczestnictwo w celebrowanych obrzędach.

Należy pamiętać o tym, że w Mszale rzymskim przewidziano mszę świętą z udziałem dzieci, a nie mszę świętą dla dzieci. Albowiem to nie dzieci, lecz całe zgromadzenie liturgiczne złożone z osób w podeszłym wieku, dorosłych, młodzieży i dzieci uczestniczy we mszy świętej. Toteż adresatem homilii jest całe wielorako zróżnicowane zgromadzenie liturgiczne. Nikogo nie można eliminować spośród adresatów głoszonej homilii i celebrowanej liturgii.

Skuteczniejsze jest formowanie rodziców, którzy są bezpośrednimi wychowawcami dzieci, aniżeli formowanie dzieci bez formowania rodziców. Dla wielu z nich przecież homilia niedzielna pozostaje jednym z wyjątkowych momentów kontaktu ze słowem Bożym. Przypominanie rodzicom o odpowiedzialności za religijne wychowanie swoich dzieci jest ważnym wyzwaniem duszpasterskim w Polsce. Rodzice nie powinni cedować duchowej formacji dzieci na duszpasterzy 
i katechetów ${ }^{81}$. W starożytnym chrześcijaństwie wychowanie religijne dzieci należało do rodziców. Oni głosili swoim dzieciom Jezusa Chrystusa i wprowadzali je w świat wartości, które sami przyjmowali ${ }^{82}$. Rodzice są głównymi wychowawcami swoich dzieci również w zakresie wychowania religijnego. Jedynie wspólna, skoordynowana współpraca duszpasterzy - głosicieli słowa Bożego, katechetów i rodziców stwarza solidne fundamenty dla wzrostu dzieci w wierze ${ }^{83}$.

\section{Bibliografia}

Bugnini A., The Reform of the Liturgy 1948-1975, trans. M. O'Connell, Collegeville, MN 1990.

DeLeers S., A Process for the Assessment of Liturgical Preaching Reflecting Official Roman Catholic Understanding of the Homily. Thesis Project Presented to the Faculty of the Aquinas Institute of Theology, Saint Louis, MO, Ann Arbor, MI 1996.

II Sobór Watykański, Konstytucja dogmatyczna o Kościele Lumen gentium (4.12.1963).

II Sobór Watykański, Konstytucja o liturgii świętej, Sacrosanctum concilium (4.12.1963).Hermans J., Celebrować Eucharystie $z$ dziećmi. Możliwości i granice nowego zjawiska liturgicznego

\footnotetext{
${ }_{81}$ Por. H. Sławiński, recenzja: Łysy Hubert, Liturgiczne i pozaliturgiczne przepowiadanie do dzieci w Kościele w Polsce po Soborze Watykańskim II. Teoria i praktyka, Redakcja Wydawnictw Wydziału Teologicznego UO, nr 120, Opole 2011, s. 249, „Ateneum Kapłańskie” 619 (2012), z. 3, s. 607-6o9.

${ }_{22}$ Ciekawie na temat troski Kościoła o dzieci napisał prof. uniwersytetu w Essen Hubertus Lutterbach w artykule Hohe Wertschatzung. Kinder und ihr Schutz in der Geschichte des Christentums, „Herder Korrespondenz” 64 (2010) nr 6, s. 290-294. ${ }_{3}$ H. Sławiński, Homilia do dzieci - pedagogiczne wyzwanie, „Msza Święta” 787 (2012) nr 5, s. 9-12.
} 
wedtug „Dyrektorium o Mszach św. dla dzieci”, „Communio” 5 (1985), s. 107-124.

Jan Paweł II, Katechizm Kościoła Katolickiego (11.10.1992).

Jan Paweł II, Przemówienie do uczestników zgromadzenia plenarnego Kongregacji ds. Duchowieństwa, Parafia i jej pasterz (23.11.2001), „L'Osservatore Romano” 242 (2002), nr 4, s. 29-30.

Kongregacja ds. Kultu Bożego i Dyscypliny Sakramentów, Redemptionis sacramentum (25.03.2004).

Kongregacja Kultu Bożego i Dyscypliny Sakramentów, Liturgiam authenticam (28.03.2001).

Kosmana I., Jak mówić dzieciom o Bogu, w kościele i w domu, „Łódzkie Studia Teologiczne” 19 (2010), s. 81-103.

Kunzler M., Liturgia Kościoła, Poznań 1999.

Święta Kongregacja Kultu Bożego, Liturgicae instaurationes (5.09.1970).

Lutterbach H., Hohe Wertschatzung. Kinder und ihr Schutz in der Geschichte des Christentums, „Herder Korrespondenz” 64. (2010), nr 6, s. 290-294.

Międzydykasterialna instrukcja o niektórych kwestiach dotyczących współpracy wiernych świeckich w ministerialnej posłudze kapłanów, Ecclesiae de misterio (15.08.1997).

Kongregacja Kultu Bożego i Dyscypliny Sakramentów, Nowe ogólne wprowadzenie do Mszału rzymskiego. $Z$ trzeciego wydania Mszału rzymskiego (18.03.2002), Poznań 2004.

Przybyłowski J., Msza święta dla dzieci. Refleksja teologiczno-pastoralna, „Ateneum Kapłańskie” 154 (2010), z. 2 (606), s. 325-333.

Ratzinger J., Nowa pieśń dla Pana. Wiara w Chrystusa a liturgia dzisiaj, tłum. J. Zychowicz, Kraków 1999.

Kongregacja Kultu Bożego i Dyscypliny Sakramentów, Redemptionis sacramentum (25.03.2004).

Sieg T.H., Models of Preaching, „Worship” 59 (1985), nr 3, s. 220-230. 
Sławiński H., Homilia do dzieci - pedagogiczne wyzwanie, „Msza Święta" 787 (2012), nr 5, s. 9-12.

Sławiński H., Liturgia słowa i liturgia eucharystyczna jako jeden akt liturgiczny, „Przegląd Homiletyczny” 11 (2007), s. 19-32.

Sławiński H., Między ciagłościa a zmiana. Teoria homilii w Stanach Zjednoczonych po II Soborze Watykańskim, Kraków 2008, Sławiński H., recenzja: Łysy Hubert, Liturgiczne i pozaliturgiczne przepowiadanie do dzieci w Kościele w Polsce po Soborze Watykańskim II. Teoria i praktyka, Opole 2011, „Ateneum Kapłańskie” 619 (2012), z 3, s. 607-609.

Święta Kongregacja ds. Sakramentów i Kultu Bożego, Inaestimabile donum (3.04.1980).

Święta Kongregacja Kultu Bożego, Instrukcja Actio pastoralis (15.05.1969). 
A* Uniwersytet Papieski 